\title{
Effect of Soil Moisture Regimes on Seed Iron and Zinc Concentration of Biofortified Bean Genotypes against Malnutrition in Sud-Kivu Highlands
}

\author{
Casinga Mubasi Clérisse ${ }^{1}$, Neema Ciza Angélique ${ }^{3}$, Kajibwami Cikuru Marie-Angélique ${ }^{1}$, \\ Nabahungu Nshwarasi Leon ${ }^{2} \&$ Mambani Banda Pierre ${ }^{4}$ \\ ${ }^{1}$ Molecular Biology Laboratory, International Institute of Tropical Agriculture, Bukavu, Sud-Kivu, Democratic \\ Republic of Congo \\ ${ }^{2}$ Soil Laboratory, International Institute of Tropical Agriculture, Bukavu, Sud-Kivu, Democratic Republic of \\ Congo \\ ${ }^{3}$ Faculté des sciences Economiques, Economie rurale, Université Evangélique en Afrique, Bukavu, Sud-Kivu, \\ Democratic Republic of Congo \\ ${ }^{4}$ Faculté des Sciences, Université de Kisangani, Kisangani, Province de la Tshopo, Democratic Republic of \\ Congo \\ Correspondence: Casinga Mubasi Clérisse, Molecular Biology Laboratory, International Institute of Tropical \\ Agriculture, Bukavu, Sud-Kivu, Democratic Republic of Congo. Tel: 243-994-717-417. E-mail: \\ c.casinga@cgiar.org
}

Received: June 10, 2017

Accepted: October 22, $2017 \quad$ Online Published: November 15, 2017

doi:10.5539/jas.v9n12p241

URL: https://doi.org/10.5539/jas.v9n12p241

\begin{abstract}
This study investigated the influence of three soil moisture irrigation regimes on concentration of seed iron and zinc content of four biofortified bean varieties promoted for eradication of malnutrition in Sud-Kivu highlands. A field experiment was conducted in the Hogola marsh highlands during two cultural seasons B2013 and B2014. The experiment design was a RCBD with a split plot arrangement where the main plots were $110 \mathrm{~m}^{2}$ and split plots $20 \mathrm{~m}^{2}$. A strategic application of homogenisation of the experimental site's soil fertility by chemical fertilizers of the type: $\mathrm{CaCO}_{3}, \mathrm{KCl}$ and DAP was conducted out. Four biofortified varieties (CODMLB001, RWR2245, HM21-7 and RWK10) constituted main factor, while water regimes respectively [bottom of the slope: $\mathrm{R} 1=48 \%$ soil moisture, at the middle of the slope $\mathrm{R} 2=37 \%$ soil moisture and at the top of the slope: $\mathrm{R} 3=29 \%$ soil moisture according to the gradient of humidity] represented secondary factor and seasonality, tertiary factor. The study showed that the concentrations of iron and zinc were highly correlated with soil moisture regimes. The variety HM21-7 demonstrated better adaptability because it showed a low rate of reduction of iron and zinc concentration under the three soil moisture regimes and was therefore best suited to fight malnutrition in the Sud-Kivu province.
\end{abstract}

Keywords: micronutrients, malnutrition, Sud-Kivu highlands, $\mathrm{CaCO}_{3}, \mathrm{KCl}$ and DAP

\section{Introduction}

Bean (Phaseolus vulgaris) is one of the oldest world cultures preferentially consumed in the human diet due to its gastronomic (Broughton et al., 2002; Beebe, 2010; Silva et al., 2012; Casinga et al., 2016a, 2016b), culinary (Dinste, 2012; Garden-Robinson \& McNeal, 2013) and socio-cultural (Dinste, 2012) specificities. Although faced with several environmental constraints throughout its vital life cycle, it is cultivated in more than 20 countries in Southern, Central and Eastern Africa owing to its adaptability to several ecological niches and so occupies more than four million hectares (Broughton et al., 2002; Hacisalihoglu et al., 2005; Yasar et al., 2008; Casinga et al., 2016a). Under swamped conditions, beans stomata remain closed for long periods, resulting in reduced respiration, transpiration and photosynthesis (Boru et al., 2003; Casinga et al., 2015a). Plants may be slow to recover when water recedes. Long-term impacts on the crop are often related to disease infection and retarded root development that limits access to available subsoil moisture later in the season (Naeve, 2002, Boru et al., 2003). Researchers noted that flooding during critical reproductive stages affect yield components including pod number and seed size (Casinga et al., 2015a, 2016a). Despite its agro-ecological potential, 
Sud-Kivu is confronted with a strong population explosion, which, coupled with the absence of a coherent land policy (Casinga et al., 2015b, 2016a, 2016b, 2016c), leading to shortage of arable land and the consequent decline in the production of food crops, including beans due to the use of marginal land, including marshes constituting more than $40 \%$ of arable land and varieties in full degeneration (Mugangu, 2008; UtshudiOna, 2009; Casinga et al., 2016b, 2016c). This plunges its population into poverty and food insecurity following a rate of chronic protein-energy malnutrition of about 43.7\% (Mastaki, 2006; PRONANUT, 2013; Casinga et al., 2016b). Owing to its nutritional richness due to the presence of several macro and micronutrients whose concentrations vary according to the genotype and within genotype (Hacisalihoglu et al., 2005). Besides, this culture has several medicinal properties such as lowering cholesterol (Rosa et al., 1998; Brown et al., 1999; Bourdon et al., 2001; Drewnowski, 2010; Casinga et al., 2016a), coronary heart disease and hypertension (Anderson et al., 2009; Bazzano et al., 2001; Papanikolaou \& Fulgoni, 2008), decrease of diabetes, obesity and overweight (Geil \& Anderson, 1994; Ledikwe, 2004), favorable effects against cancer (Hangen \& Bennink, 2002), high capicity to act as oxidizer (Heimler et al., 2005), the ability to act against gene mutation (Azevedo et al., 2003), produces an antiproliferative effect (Aparicio-Fernández et al., 2006) and reduces digestive disorders (Williams et al., 2008 and stamps out anemia (Holland et al., 1991). Moreover, its cultivation cycle lasts only three months and thus can be grown throughout the year and used as a bridging food due to the agro-ecological diversity of the study area and its multiple products (Wortmann, 1998; Grubben et al., 2004). In addition, through biofortification which is a varietal improvement approach which consists in introgressing, by crossing, the genes that confer micronutrient content, which are the trace elements (mainly iron and zinc) and vitamins (Vitamin A) in plants containing them Less or not (Harvest Plus, 2010).

The objective of this study is to identify the best-performing biofortified bean varieties in Iron and Zinc concentration under periodically flooded swampy lowlands conditions in order to popularize them in households to eradicate malnutrition in this constrained area and to improve the livelihoods of the population.

\section{Method}

\subsection{Location}

The experiment was carried out in Hogola marsh, Karhongo-Nyangezi grouping, that is located in the Ngweshe chieftaincy ofWalungu Territory, Sud-Kivu, Democratic Republic of Congo. The geographical coordinates of the station are $28^{\circ} 51^{\prime}$ East longitude and $2^{\circ} 28^{\prime}$ South latitude whereas the altitude is $1563 \mathrm{~m}$.

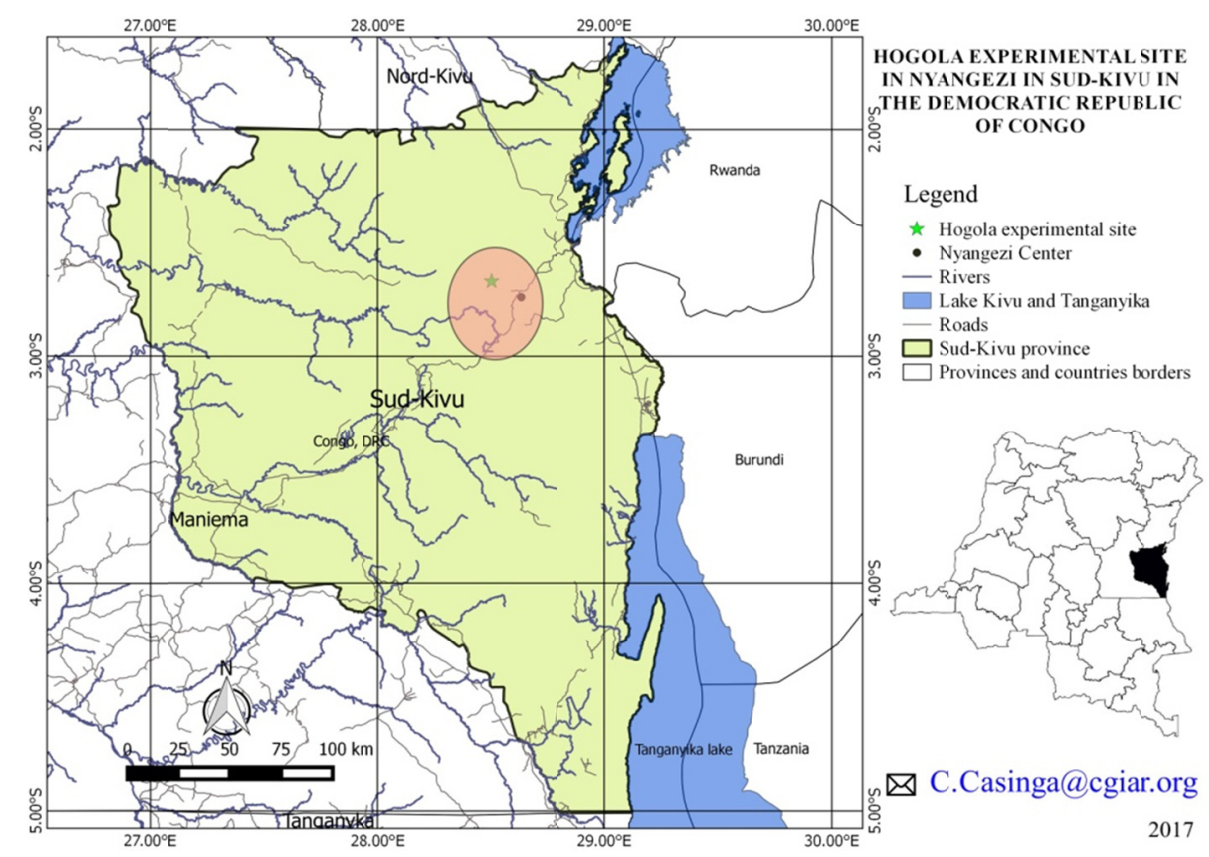

Figure 1. Hogola experimental site in Nyangezi in Sud-Kivu in the Democratic Republic of Congo 
Hogola enjoys a $\mathrm{AW}_{3}$ climate type of Köppen's classification and its soil are classified as Ferralsol according to the FAO-UNESCO (Baert, 1995; Beernaert, 1999; Botula et al., 2012) while its texture is clay-silty (Casinga et al., 2015a, 2016b, 2016c). Subsistence agriculture remains the main activity in our experimentation area in spite of land degradation correlated to the exponential population increase.

\subsection{Materials}

The experimental material consisted of four varieties of biofortified bean: CODMLB001, HM21-7, RWR2245 and RWK10, and chemical fertilizers; $\mathrm{CaCo}_{3}$, DAP (18-46-0) and $\mathrm{KCl}$ fertilizers with $60 \%$ concentration in $\mathrm{K}$.

\subsection{Implementation of Tests}

After clearing the land of weeds using a machete, the experimental site $\left(1280 \mathrm{~m}^{2}\right)$ was plowed twice with a hoe to a depth of $30 \mathrm{~cm}$ in an interval of 10 days and then manually harrowed with a rake. The land was then subdivided into blocks, plots and sub-plots. Conducted under RCBD design with a split plot arrangement. The blocks were three and parallel on a slope. Their dimensions were $5.5 \mathrm{~m} \times 62 \mathrm{~m}$ and separated from each other by a distance of $0.75 \mathrm{~m}$. Three plots of $5.5 \mathrm{~m} \times 20 \mathrm{~m}$ were delineated within each block at the bottom of the slope ( $\mathrm{R} 3=48 \%$ soil moisture), at the middle of the slope $(\mathrm{R} 2=37 \%$ soil moisture $)$ and at the top of the slope ( $\mathrm{R} 1=$ $29 \%$ soil moisture) according to the gradient of humidity, so as to represent three water regimes within each block. Four sub-plots of $1 \mathrm{~m} \times 20 \mathrm{~m}$ parallel to the slope were in turn demarcated within each plot.

At the physiological maturity stage, 60 well filled and non-soiled pods were collected on 30 plants located on three central lines of each experimental unit (excluding edging plants) and then shelled and sorted. The healthy seeds were then analyzed to determine the iron and zinc content by atomic absorption after extraction with Triamine Pentacetique acid according to Chauhan et al. (1981) and Okalebo et al. (2002).

Four soil samples were collected using a hole at $25 \mathrm{~cm}$ depth in each experiment plot. The latter were mixtured to form a composite sample on which the measurements were made before the sowing date.

Soil moisture was measured by the gravimetric method and in addition soil moisture characteristics $\theta\left(\varphi_{\mathrm{m}}\right)$ were determined by the table methods of suction and pressure membrane, respectively for the range of matric potential superior to -0.01 MPa and lower to -0.01 MPa according to the procedure described by Okalebo et al. (2002). Two composite soil samples from each sub-plot taken $25 \mathrm{~cm}$ subterranean at the vegetative stage $\mathrm{V}_{3}$ and harvest stages were analyzed according to Kjeldahl (1883) method' for Nitrogen, while Olsen et al. (1954) method' was used for the estimation of available phosphorus in soils. In addition, potassium was analyzed by Dognin's (1981) method. DAP (18-46-0), $\mathrm{KCl}$ with $60 \%$ concentration in $\mathrm{K}$ and $\mathrm{CaCO}_{3}$ chemical fertilizers were applied strategically according to the level of the NPK elements in each experimental unit in order to standardize the fertility level of the experimental units. The development of the plots described above made it possible to conduct the experiment according to a factorial model in an experimental split-plot device.

In this study, biofortified bean varieties randomized and sowed in-line in sub-plots at $4 \mathrm{~cm}$ depth with two seeds per pooled at $20 \times 20 \mathrm{~cm}$ were the main factor, while water regimes represented the secondary factor.

The experimentation was conducted in two seasons (February-June 2013 and February-June 2014). These constituted the tertiary factor.

\subsection{The Observed Parameters}

The concentration of iron and zinc content in dry plant biomass at the vegetative stage V3 and in seeds, micronutrient loss content, as well as water regimes were determined.

\subsection{Statistical Analyses}

The experimental results were evaluated by the analyses of variance, correlation and multiple regression whereas the means were separated by the $\mathrm{LSD}_{\alpha=0.05}$ test.

Excel 2013, R 3.3.0 and Assistat 9.5.1 software were used as a calculation tools.

\section{Results}

\subsection{Iron and Zinc Content in Dry Biomass and Seeds}

Statistical analyzes revealed significant differences both between water regimes and among varieties within different water regimes on micronutrient content $(P=0.02 ; \alpha=0.05)$. Specifically, zinc showed significant difference between the two experimental seasons and a significant difference between different water regimes whereas for iron no significant difference was observed both seasonality and water regimes for all varieties. 
Table 1. Micronutrient content in dry biomass and seed

\begin{tabular}{|c|c|c|c|c|c|c|c|c|c|c|c|c|}
\hline \multirow{4}{*}{ Varieties } & \multicolumn{6}{|c|}{ Micronutrient content in biomass } & \multicolumn{6}{|c|}{ Micronutrient content in seeds } \\
\hline & \multicolumn{3}{|c|}{ Iron $(\mathrm{mg} / \mathrm{g})$} & \multicolumn{3}{|c|}{ Zinc (mg/g) } & \multicolumn{3}{|c|}{ Iron $(\mathrm{mg} / \mathrm{g})$} & \multicolumn{3}{|c|}{ Zinc (mg/g) } \\
\hline & $\mathbf{R} 1$ & $\mathbf{R 2}$ & $\mathbf{R 3}$ & R1 & $\mathbf{R 2}$ & $\mathbf{R 3}$ & R1 & $\mathbf{R 2}$ & R3 & $\mathbf{R 1}$ & $\mathbf{R 2}$ & $\mathbf{R 3}$ \\
\hline & S1 S2 & S1 S2 & S1 S2 & S1 S2 & S1 S2 & S1 S2 & S1 S2 & S1 S2 & S1 S2 & S1 S2 & S1 S2 & $\mathbf{S} 1 \mathbf{S 2}$ \\
\hline CODMLB001 & $42 \quad 30$ & $54 \quad 59$ & 7576 & 1518 & 2528 & 3134 & 2629 & 5459 & 7576 & 1922 & 2528 & 3134 \\
\hline RWR2245 & $28 \quad 32$ & $28 \quad 26$ & 4649 & $17 \quad 14$ & 2525 & 2832 & 2428 & 2826 & $46 \quad 49$ & 2223 & $25 \quad 25$ & 2832 \\
\hline HM21-7 & 3639 & $45 \quad 42$ & 5860 & 1815 & 2628 & 3233 & 2929 & $45 \quad 42$ & 5860 & 2220 & 2628 & 3233 \\
\hline RWK10 & $29 \quad 29$ & $31 \quad 32$ & 4447 & $21 \quad 19$ & 2927 & $33 \quad 34$ & $23 \quad 24$ & $31 \quad 32$ & $44 \quad 47$ & 2623 & 2927 & $33 \quad 34$ \\
\hline Seasons average & 3433 & 4040 & 5658 & 1817 & 2627 & 3133 & 2323 & 3132 & $44 \quad 47$ & 2623 & 2927 & 3334 \\
\hline Content in water regimes average & 33.1 & 39.5 & 56.9 & 17.1 & 26.7 & 32.1 & 23.4 & 31.4 & 45.5 & 24.5 & 28 & 33.7 \\
\hline Micronutrient loss content average & & & & HM2 & $-7>\mathrm{RW}$ & KK10> & $2245>$ & CODM & LB001 & & & \\
\hline
\end{tabular}

Note. $\mathrm{R} 1=$ The top of the landscape, $\mathrm{R} 2=$ The middle of the land scape, $\mathrm{R} 3=$ The bottom of the landscape, $\mathrm{S} 1=$ B2013 season and $\mathrm{S} 2=\mathrm{B} 2014$ season.

Cumulative seasonal averages of Iron and $\mathrm{Zn}$ contents in the dry aerial biomass at the vegetative stage V3 drastically decrease from the top to the bottom of the hill, starting from the water regimes R3 and R1 according to the seasons and the biofortified bean varieties (Table 1). Thus, in season S1, the reductions in Fe content were 55.8 and 33.6 compared with 58 and 32.5 in season S2. Similarly, the reductions in Zinc content were 31 and 17.8 in the $\mathrm{S} 1$ season against 33.1 and 16.5 in the $\mathrm{S} 2$ season.

Iron and Zinc contents in seeds followed the same trends as observed in aerial parts of the crop. However, rates of reduction of nutrient contents in varieties varied in the order of HM21-7 > RWK10 > RWR2245 > CODMLB001.
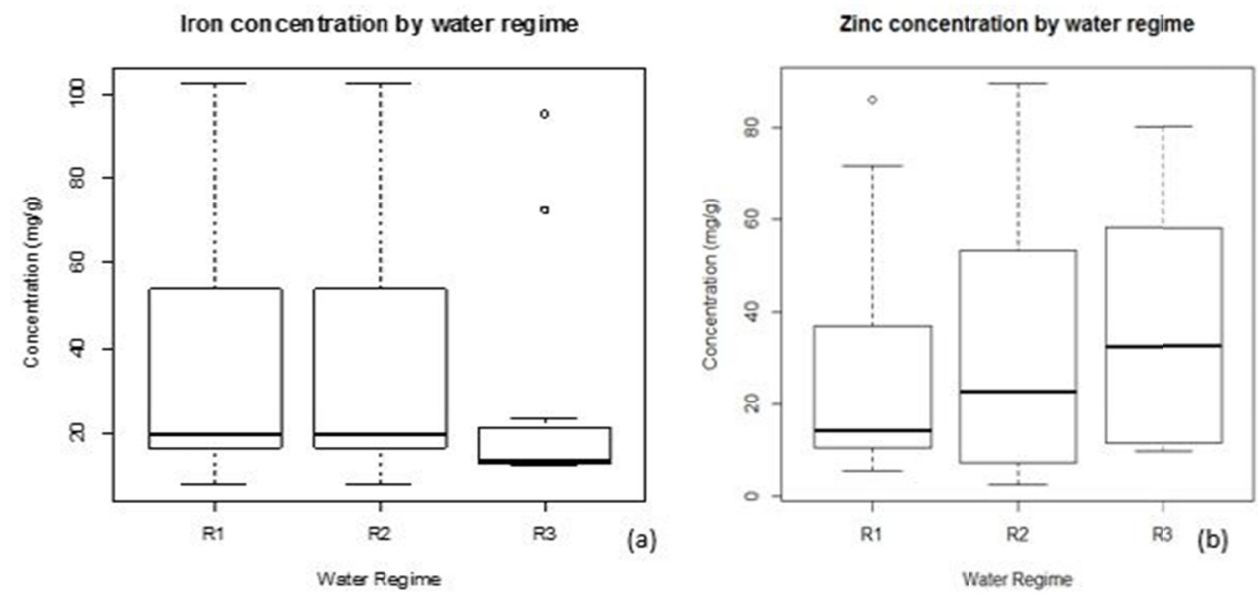

Figure 2. Correlation between micronutrient content and water regime in dry biomass and seed

Note. $\mathrm{R} 1=$ The top of the landscape, $\mathrm{R} 2=$ The middle of the land scape, $\mathrm{R} 3=$ The bottom of the landscape.

The Figure 2 above highlight correlation between the concentrations of iron and zinc content and the water regime, thus showing the influence of water nutrition on the nutrient concentration.

In the Results section, summarize the collected data and the analysis performed on those data relevant to the discourse that is to follow. Report the data in sufficient detail to justify your conclusions. Mention all relevant results, including those that run counter to expectation; be sure to include small effect sizes (or statistically nonsignificant findings) when theory predicts large (or statistically significant) ones. Do not hide uncomfortable results by omission. Do not include individual scores or raw data with the exception, for example, of single-case designs or illustrative examples. In the spirit of data sharing (encouraged by APA and other professional associations and sometimes required by funding agencies), raw data, including study characteristics and indivldual effect sizes used in a meta-analysis, can be made available on supplemental online archives. 


\section{Discussion}

Plants respond differently to environmental stress by adopting and developing adaptive mechanisms according to Chaves et al. (2003) and Casinga et al. (2015c, 2016b), confirming the results of the different varieties of biofortified bean obtained in the study site. HM21-7 developed good adaptation to by maintaining high Iron and Zinc concentration under this water excess stress. The major effect of excess of moisture on plants is the alteration of the hormonal balance and dry matter concentration and inhibition of photosynthesis and micronutrient uptake (Nunez-Elisea et al., 1999; Pezeshki, 2001; Dat et al., 2004; Kreuzwieser et al., 2004) confirming the decrease of our four genotypes of the micronutrient content of Iron upstream [CODMLB001 $(81><40.5 \mathrm{mg} / \mathrm{g})$; RWR2245 (52 > $<42.5 \mathrm{mg} / \mathrm{g})$; HM21-7 $(62><40.7 \mathrm{mg} / \mathrm{g})$ and RWK10 $(55><37.9$ $\mathrm{mg} / \mathrm{g})$ ] and of Zinc content downstream [CODMLB001 (34 >< $13 \mathrm{mg} / \mathrm{g})$; RWR2245 (34 >< $16 \mathrm{mg} / \mathrm{g})$; HM21-7 $(33><18 \mathrm{mg} / \mathrm{g})$ and RWK10 $(35><11 \mathrm{mg} / \mathrm{g})]$ during the two experimental seasons. Besides, it confirms the results of Pfeiffer and McClafferty's (2007) work, as well as that of Silva et al. (2012) attesting that biofortified bean's contents in Iron and Zinc is not only genotypical, but like any quantitative character, it is also influenced by environmental factors (agronomic, climatic and edaphic) and $\mathrm{G} \times \mathrm{E}$ interactions such as differential genotype responses to agronomic, climatic and edaphic factors.

\section{Conclusion}

The concentrations of Iron and Zinc contents are highly correlated with water regimes. It is up to the population living in the mountainous and marginal soils of mountainous Sud-Kivu to cultivate the variety HM21-7 under the three water regimes in case of inaccessibility to arable land. As to national and international organizations, they should popularize the variety HM 21-7 according to the agro-ecological zones because it is best suited to curb malnutrition in the province of Sud-Kivu.

\section{References}

Anderson, J. W., Baird, P., Davis, R. H., Ferreri, S., Knudtson, M., \& Koraym, A. (2009). Health benefits of dietary fiber. Nutr. Rev., 67(4), 188-205. https://doi.org/10.1111/j.1753-4887.2009.00189.x

Aparicio-Fernández, X., García-Gasca, T., Yousef, G. G., Lila, M. A., González de Mejía, E., \& Loarca-Piña, G. (2006). Chemopreventive activity of polyphenolics from black Jamapa bean (Phaseolus vulgaris L.) on HeLa and HaCaT cells. J. Agric. Food Chem, 54, 2116-2122. https://doi.org/10.1021/jf052974m

Azevedo, L., Gomes, J. C., Stringheta, P. C., Gontijo, A. M., Padovani, C. R., Ribeiro, L. R., \& Salvatori, D. M. (2003). Black bean (Phaseolus vulgaris L.) as protective agent against DNA damage in mice. Food Chem. Toxicol., 41, 1671-1676. https://doi.org/10.1016/S0278-6915(03)00173-X

Baert, G. (1995). Properties and chemical management aspects of soils on different parent rocks in the Lower Zaire (PhD Thesis, Ghent University, Belgium).

Bazzano, L. A., He, J., Ogden, L. G., Loria, C., Vapputuri, S., Myers, L., \& Whelton, P. K. (2001). Legume consumption and risk of coronary heart disease in US men and women. Arch. Int. Med., 161, 2528. https://doi.org/10.1001/archinte.161.21.2573

Beebe, S. (2010). Bean Biofortifid. Harvet Plus. Retrieved January 27, 2010, from http://www.harvestplus.org/ publications

Beernaert, F. R. (1999). Feasibility Study of a Production Project of Lime and/or Ground Travertine for the Management of Acid Soils in Rwanda (p. 287). PRO-INTER Project Consultants, Belgium.

Boru, G., Vantoai, T., Alves, J., Hua, D., \& Knee, M. (2003). Responses of Soybean to Oxygen Deficiency and Elevated Root-zone Carbon Dioxide Concentration. Annals of Botany, 91, 447-453. https://doi.org/10.1093/ $\mathrm{aob} / \operatorname{mcg} 040$

Botula, Y.-D., Cornelis, W. M., Baert, G., \& Van Ranst, E. (2012). Evaluation of pedotransfer functions for predicting water retention of soils in Lower Congo (D.R. Congo). Agricultural Water Management in Elsevier, 111, 1-10. https://doi.org/10.1016/j.agwat.2012.04.006

Bourdon, I., Olson, B., Backus, R., Richter, B. D., Davis, P. A., \& Schneeman, B. O. (2001). Beans, as a source of dietary fiber, increase cholecystokinin and apolipoprotein B48 response to test meals in men. J. Nutr., 131, 1485-1490.

Broughton, W. J., Hernandez, G., Blair, M., Beebe, S., Gepts, P., \& Vanderleyden, J. (2002). Beans (Phaseolus spp.) - Model food legumes. Plant and Soil, 252, 55-128. https://doi.org/10.1023/A:1024146710611 
Brown, L., Rosner, B., Willett, W. W., \& Sacks, F. M. (1999). Cholesterol-lowering effects of dietary fiber: A meta-analysis. Am. J. Clin. Nutr., 69, 30-42.

Casinga, C. M. (2015a). Etude comparative des réponses de quatre variétés d'haricots bio fortifiés à trois régimes hydriquesdans le Sud-Kivu montagneux: Cas de Hogola. Mémoire de maitrise (p. 82). Université Evangélique en Afrique.

Casinga, C. M., Cirimwami, L. T., Amzati, S. G., Kaningini, E. B., Lubobo, A. K., Katembera, J. I., \& Mushagalusa, G. N. (2015c). Effect of the environment on the adaptability of biofortified bean genotypes in the Eastern Democratic Republic of Congo: Case of South Kivu. European Journal of Agriculture and Forestry Research, 3(9), 38-47.

Casinga, C. M., Cirimwami, L. T., Amzati, S. G., Kaningini, E. B., \& Lubobo, A. K. (2016a). Effet du stress hydrique sur le criblage variétal des haricots communs (Phaseolus vulgaris) dans le marais du Sud-Kivu montagneux. Afrique Science, 12(1), 335-344.

Casinga, C. M., Cirimwami, L. T., Bisimwa, E. B., \& Mushagalusa, G. N. (2015b). The impact of leguminous culture system and sowing dates on the cereal yield in mountainous South-Kivu: Burhale case. International Journal of Innovation and Scientific Research, 18(2), 297-303.

Casinga, C. M., Haminosi, G., \& Cirimwami, L. T. (2016c). Determining Optimal Dose of Chemical Fertilizer on Biofortified Bean in Sud-Kivu Highlands. J. Agr. Sci., 9(1), 128-133.

Casinga, C. M., Kanyenga, A. L., \& Mambani, P. B. (2016b). Les haricots biofortifiés sous stress hydrique au Sud-Kivu montagneux. EUE, 76.

Chauhan, O. S., Garg, B. S., \& Singh, R. P. (1981). A rapid spectrophotometric method for determination of zinc in milk. Talanta, 28, 399-401. https://doi.org/10.1016/0039-9140(81)80193-2

Chaves, M., Maroco, J., \& Pereira, J. (2003). Understanding plant responses to drought from genes to the whole plant. Funct. Plant Biol., 30, 239-264. https://doi.org/10.1071/FP02076

Dat, J., Capelli, N., Folzer, H., Bourgeade, P., \& Badot, P. (2004). Sensing and signalling during plant flooding. Plant Physiol. Biochem., 42, 273-282. https://doi.org/10.1016/j.plaphy.2004.02.003

Dinstel, R. R. (2012). Cooking Dried Beans, Peas and Lentils (p. 20). University of Alaska Fairbanks.

Dognin, O., Mégie, C., Louis, R., \& Sément, G. (1981). Dynamique du potassium échangeable dans les sols tropicaux cultivés. Coton et Fibres Tropi, 36(2), 191-204.

Drewnowski, A. (2010). The Nutrient Rich Foods Index helps to identify healthy, affordable foods. Am. J. Clin. Nutr., 91, 1095-1101. https://doi.org/10.3945/ajen.2010.28450D

Garden-Robinson, J., \& McNeal, K. R. D. (2013). Nutrition, Health benefits, Preparation and use in menus. Northarvest-Beans, 16.

Geil, P. B., \& Anderson, J. W. (1994). Nutrition and health implications of dry beans: A review. J. Am. Coll. Nutr., 13, 549-558. https://doi.org/10.1080/07315724.1994.10718446

Hacisalihoglu, G., Kochian, L. V., \& Vallejos, C. E. (2005). Distribution of seed mineral nutrients and their correlation in Phaseolus vulgaris. Proc. Fla. State Hort. Soc., 118, 102-105.

Hangen, L., \& Bennink, M. R. (2002). Consumption of black beans and navy beans (Phaseolus vulgaris) reduced azoxymethaneinduced colon cancer in rats. Nutr. Cancer, 44, 60-65. https://doi.org/10.1207/ S15327914NC441_8

Harvest Plus. (2010). Rapport annuel du CIAT (p. 30). Harvest Plus.

Heimler, D., Vignolini, P., Dini, M. G., \& Romani, A. (2005). Rapid tests to assess the antioxidant activity of Phaseolus vulgaris L. dry beans. J. Agric. Chem., 53, 3053-3056. https://doi.org/10.1021/jf049001r

Holland, B., Unwin, I. D., \& Buss, D. H. (1991). Vegetables, herbs and spices. The Fifth Supplement to McCance and Widdowson's, The Composition of Foods (4th ed.). Royal Society of Chemistry, Cambridge, United Kingdom.

Kjeldahl, J. (1883). Neue Methode zur Bestimmung des Stickstoffs in organischen Körpern. Z. Anal. Chem., 22, 366-382. https://doi.org/10.1007/BF01338151

Kreuzwieser, J., Papadopoulou, E., \& Rennenberg, H. (2004). Interaction of flooding with carbon metabolism of forest trees. Pl. Bio., 6, 299-306. https://doi.org/10.1055/s-2004-817882 
Ledikwe, J. H., Smiciklas-Wright, H., Mitchell, D. C., Miller, C. K., \& Jensen, G. L. (2004). Dietary patterns of rural older adults are associated with weight and nutritional status. J. Am. Geriatr. Soc., 52, 589-595. https://doi.org/10.1111/j.1532-5415.2004.52167.x

Mastaki, J. L. N. (2006). Le rôle des goulots d'étranglement de la commercialisation dans ladoption des innovations agricoles chez les producteurs vivriers du Sud-Kivu (p. 267). Faculté Universitaire des Sciences Agronomiques de Gembloux.

Mugangu, S. (2008). La crise foncière à l'Est de la République Démocratique du Congo. L'Afrique Des Grands Lacs. Annuaire (pp. 385-414).

Naeve, S. (2002). Flooded fields and soybean survival. Minnesota Crop News, July 14. University of Minnesota, USA. Retrieved from http://www.extension.umn.edu/cropEnews/2002/02MNCN26.htm

Nunez-Elisea, R., Schaffer, B., Fisher, J., Colls, A., \& Crane, J. (1999). Influence of flooding on net $\mathrm{CO}_{2}$ assimilation, growth and stem anatomy of annona species. Annuals of Botany, 84, 771-780. https://doi.org/10.1006/anbo.1999.0977

Okalebo Robert, J., Gathwa, W. K., \& Woomer, L. P. (2002). Laboratory methods of soil and plant analysis: A working manual (2nd ed., p. 88).

Olsen, S. R., Cote, C. V., Watanabe, F. S., \& Dean, L. A. (1954). Estimation of available phosphorus in soils by extraction with sodium bicarbonate. USDA Circular, 939, 8.

Papanikolaou, Y., \& Fulgoni, V. L. (2008). Bean consumption is associated with greater nutrient nintake, reduced systolic blood pressure, lower body weight, and a smaller waist circumference in adults: Results from the National Health and Nutrition Examination Survey 1999-2002. J. Am. Coll. Nutr., 27(5), 569-576. https://doi.org/10.1080/07315724.2008.10719740

Pezeshki, S. (2001). Wetland plant responses to soil flooding. Env. and Exper. Bot., 46, $299-312$. https://doi.org/10.1016/S0098-8472(01)00107-1

Pfeiffer, W., \& McClafferty, B. (2007). HarvestPlus: Breeding crops for better nutrition. Crop Science, 47(3), 88-105. https://doi.org/10.2135/cropsci2007.09.0020IPBS

Programme National de Nutrition (RONANUT). (2013). Enquêtes nutritionnelles territoriales province du Sud-Kivu: Rapport synthèse (p. 24).

Rosa, C. O. B., Costa, N. M. B., Nunes, R. M., \& Leal, P. F. G. (1998). The cholesterol-lowering effect of black beans (Phaseolus vulgaris L.) in hypocholesterolemic rats. Arch. Latinoam. Nutr., 48, 306-310.

Silva, C. A., Abreu, Â. F. B., Ramalho, M. A. P., \& Corrêa, A. D. (2012). Interaction genotype by season and its influence on the identification of beans with high content of zinc and iron. Bragantia, 71(3), 336-341. https://doi.org/10.1590/S0006-87052012005000037

Utshudi-Ona, I. (2009). La décentralisation en République Démocratique du Congo: Opportunité pour une gestion foncière décentralisée. L'Afrique Des Grands Lacs. Annuaire (pp. 289-321).

Williams, P. G., Grafenauer, S. J., \& O’Shea, J. E. (2008). Cereal grains, legumes, and weight management: A comprehensive review of the scientific evidence. Nutr. Rev., 66(4), 171-182. https://doi.org/10.1111/ j.1753-4887.2008.00022.x

Wortmann, C. S., Kirkby, R. A., Eledu, C. A., \& Allen, D. J. (1998). Atlas of common bean (Phaseolus vulgaris L.) production in Africa (p. 133). CIAT Pan-African Bean Research Alliance, International Center for Tropical Agriculture (CIAT), Cali, Colombia.

Yasar, F., Üzal, Ö., Özpay, T., \& Ellialtioğlu, S. (2014). Root, stem, and leaf ion accumulation in drought-stressed green bean (Phaseolusvulgaris L.) genotypes treated with Peg-6000. J. Hortic. Sci. \& Biotec., 23(10A), 2656-2662.

\section{Copyrights}

Copyright for this article is retained by the author(s), with first publication rights granted to the journal.

This is an open-access article distributed under the terms and conditions of the Creative Commons Attribution license (http://creativecommons.org/licenses/by/4.0/). 